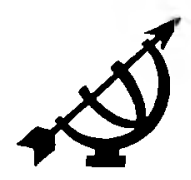

\title{
Metanationality, comprehensive democracy and left communitarian rights: lessons from Ghana for South Africa
}

\author{
Pieter Coetzee \\ Department of Philosophy \\ University of South Africa \\ PRETORIA \\ E-mail: coetzph@unisa.ac.za
}

Abstract

\begin{abstract}
Metanationality, comprehensive democracy and left communitarian rights: lessons from Ghana for South Africa

The Ghanaian philosopher, Kwame Gyekye, defends a concept of metanationality (nationality-transcending specific ethnic groups, yet accommodating them all on a basis of equality), which he regards as eminently suitable for application in multicultural societies. Metanationality distinguishes between first- and second-tier solidarity. Second-tier solidarity entails commitment to the democratic institutions of the state and a system of rights to which individuals bear title. These rights include social and economic rights which are backup rights ensuring effective use of political rights. This system of comprehensive democracy requires that the constitution does not differentiate between citizens, though individuals are differentiated at first-tier solidarity with reference to the communocultural groups with whom they identify. Gyekye succeeds in marrying rights to a politics of the common good. This success is due largely to a novel feature of his philosophy - the equal moral standing of individual and community and to a limitation clause designed to limit liberty whenever it is necessary to protect the requirements of equality. Gyekye's attempt to find a reciprocal balance between rights and the common good is instructive for aftempts in South Africa to effect a just dispensation for all citizens.
\end{abstract}

\section{Introduction}

Kwame Gyekye defends a left-communitarianism critically founded on his view that the individual and her community are morally of equal value or standing, an idea Gyekye calls their equiprimordiality. The equiprimordiality of person and community is primarily a structural defense against 
Metanationality, comprehenswe democracy and left communitarlan rlghts

the possibility of cultural oppression of any ethnic group by another. The recognition of equal moral standing for individuals alongside their communities creates a public space for internal criticism of moral practices which runs on a capacity for moral agency partially independent of the formative influences of community. The idea, central to Gyekye's communitarianism (the idea that the community has moral significance), that neither the common interest nor individual rights are by themselves absolutely overriding or trumps, determines that the political community and its institutions are never simply the neutral umpires of individually chosen goods. This non-neutral stand is, in Gyekye, a guarantee of freedom from oppression.

Gyekye's left-communitarianism is inherently paternalistic. State interference in the private domain is not only permissible but justifiable from the point of view of capacity building. Gyekye's sense of justification connects with his concern that Africa should remain the master of her own fate, and that the African states might retain a hold on their choice of the shape of modernity provided that their governments create conditions conducive to cultural development and technological growth. This paternalism creates space for a liberal critique, yet its possibility does not dampen Gyekye's enthusiasm for communitarianism. From his perspective, a defense of communitarianism - as he modifies it with additions from liberalism - is the appropriate response to the over-individualistic liberal treatment of the person and her community, and to the sense of alienation that accompanies individuals' experience of the liberal state. Gyekye's attempt to construct a left-communitarianism on the basis of the equiprimordiality of the person and her community contains an immanent critique of the liberal alternative. Specifically, the community and the individuals who make it up are equally significant loci of value. As a source of value the community acts as a restraint on the excesses of individualism, particularly with respect to claim-rights affecting the extent of liberty. Gyekye's anti-Lockean stand is apparent in the limitations affecting the right to dispose of one's property (including one's body, one's life and one's talents) as one pleases. Individuals have responsibilities to their communities regarding the manner in which they conduct their lives, and to what ends they apply their talents. Indeed, in Gyekye's communitarian setting they are morally accountable to the community in this respect. In view of this public institutions have the power to shape the common good and to determine how it might best be served (with due consideration to the side constraints which the moral rights of individuals generate). Yet the values which the community espouses are never incontestably or selfevidently right or true. Ultimately value is determined in a contested dialogue between community mem- 
bers and even between specific individuals and their communities. This is to say that for Gyekye value is ultimately relational.

My object is to give an account of Gyekye's communitarianism and of the critique of liberalism it contains. I shall not be concerned with liberal objections to Gyekye's views and so will largely ignore the issue except where it affects points of exegesis.

\section{Rights of the collective and individual rights}

\subsection{The associative concept of community and the relational concept of personhood}

Since much of what Gyekye attempts to defend as rights (of the individual and of the community) turn on his conception of the collectivity, I begin by making some distinctions. Gyekye (1997:39-47) favours the associative concept of community, which he implicitly contrasts with the aggregative concept. Association is the view that the collective is constituted by patterns of interpersonal relationships and indeed, that the association is structured by these relationships and the (sociological, cultural, traditional) rules they imply (Bird, 1999:87-90). Individuals comprise the collective; they (re)produce the relationships which make up their association. How they do that marks the difference between strong and weak association, as we shall shortly see. According to the associative view community is "a group of persons linked by interpersonal bonds, which are not necessarily biological, who consider themselves primarily as members of a group and who share common goods, values, and interests. The notion of a shared life - shared purposes, interests, and understandings of the good" (Gyekye, 1997:42) is central to this conception.

Ontologically the community is "a reality in itself" (Gyekye, 1997:42), grounded in the "fundamentally relational character of the person and the interdependence of human individuals arising out of their natural sociality" (Gyekye, 1997:38). Relationality and sociality are necessary attributes. "The person is constituted, at least partly, by social relationships in which he necessarily finds himself" (Gyekye,1997:38). Members share a way of life; they have "intellectual and ideological as well as emotional attachments to their shared goals and values and ... they are ever ready to pursue and defend them" (Gyekye, 1997:42). Their relationships are regulated by culturally reinforced "reciprocities, comprehensive interactions, and mutual sympathies and responsibilities" (Gyekye, 1997:42) which run on "a loyalty and commitment to the community" (Gyekye, 1997:43) experienced as "the desire to advance its interests" (Gyekye, 1997:43). A community structured by such relation- 
Metanationalty, comprehensive democracy and left communitarian rights

ships and loyalties imply that in assuming the normative point of view an agent is primarily concerned with the instantiation and reproduction of these relationships and loyalties (Bird, 1999:90).

Gyekye rejects the view that community is "a mere association based on a contract of individuals whose interests and ends are contingently congruent" (Gyekye, 1997:42). This view lacks the strong normative dimension which deliberate pursuit of the common good possesses simply because, in the appropriate social context, "individuals are concerned solely and primarily with the promotion of their own interests, ends, and well-being and pay attention to the common good of the society only sporadically" (Gyekye, 1997:43). Gyekye hereby rejects the aggregative sense of the collectivity. To construe the collective as an aggregate of individuals is to treat individuals as separate units who contribute arithmetically to the whole (Bird, 1999:86-89), and who have interests only contingently connected. (Gyekye ascribes the aggregative view to Western theorists like Rawls and Dworkin.)

Strong and weak association construe the relation between individuals and the collectivities with which they identify as a "'membership' relation" (Bird, 1999:85). Strong and weak association distinguish two sets of "membership" relation: the relation between individuals and the community that they collectively constitute, and the relation between the community and the political institutions of the state that act on behalf of the community whenever the rights of individuals are at issue (Bird, 1999:86). This distinction draws a line between the public and private domains which are significant for theories that entertain the notion of individual rights in some way. Now, if individuals count as moral agents only because of their membership of a group, and act as moral agents only through the marital, paternal, and maternal structures of their groups, the relationships between individual members are said to be irreducible (Bird's term - 1999:87), and this is a characteristic of strong association. Strong association is a feature of Wiredu's theory, given the moral significance he attaches to kinship groups and lineages'. This does not mean, as Bird (1999:88) makes clear, that "the relationships defining an association ... exist apart from individuals"; strong association makes a claim "about how individuals compromise ... [the] collective"

1 See Wiredu (1996:34-42). Wiredu does make provision for individual rights vested in human beings in virtue of their intrinsic worth as human beings. This aspect of his theory makes provision for rights owed to strangers which, as a class of rights, is distinct from the 'role'-rights observed by the Akan. Akans, of course, also owe each other rights of respect vested in the intrinsic worth of persons, a right Wiredu defends as a universal norm founded in the biology of the human species. 
(Bird, 1999:88). Bird (1999:89) explains as follows. Suppose a heap of Lego bricks could be assembled in a model of the Empire State Building The model and the heap are composed of the same bricks, each in a different way. In the model "each brick ... has a specific role to play in replicating certain features of the Empire State Building. ... [The bricks] compose the model by being there in a certain spatial relationship with each other. If that model is to replicate the Empire State Building, those spatial relationships must be present: without them, it will fail to be a model of the building". The spatial relationships are irreducible, just as the interpersonal relationships on which role-rights are based in Wiredu's theory are morally irreducible. Adopting the moral point of view means instantiating and reproducing those (kinship and lineage) relationships and no others (Bird, 1999:90).

But as soon as individuals count morally as autonomous units apart from and independent of structured relationships, and qua autonomous units enjoy moral standing of equal value as that which they have in structured relationships, irreducibility is compromised. In Gyekye these relationships are organic but not structured by ethnic loyalties (Gyekye, 1997:104105). Irreducible relationships tend to diminish the moral significance of the distinction between the two sets of membership relations mentioned above. The rules by which individuals act and those by which the collective act tend to be the same set (Bird, 1999:91) which means that rights are easily transferred from individuals to the collective (Bird, 1999: 91). Social contexts in which irreducibility is more or less compromised tend to exploit the distinction to demarcate an uncompromisable space for individual rights. A disanalogy between private and public agency is apparent (Bird, 1999:91) together with a concomitant disjunction between the rules by which individuals and collectives are held to act (Bird, 1999: 91). Individuals are separable from the relationships in which they participate without loss of moral status, but in spite of the space created for disanalogy and disjunction in Gyekye's theory, the collective interest may in specific contexts become overriding. An agent's status as moral agent is not exhausted by her being an individual-as-unit; she bears title to rights but she also has responsibilities to the collective.

For Bird (1999:94) the ultimate contrast between the aggregative and the associative conceptions reduces to the proposal that the latter "privileges specific interpersonal relationships over the interests of individuals considered in isolation". I maintain that this has a significant implication for what it means to adopt the moral point of view. Bird (1999:90) supplies a comprehensive statement of this implication which I here adopt. An account of public agency may be said to be symmetrical if "the normative point of view under which the public agency acts on behalf of the collectivity is analogous to the normative point of view under which 
Metanctionality, comprehensive democracy and left communitarian rlghts

individual agents act on their own behalf", i.e. if "there are analogies between justified individual agency and justified collective or public agency" (Bird, 1999:95). Balancing this symmetry (Bird's term - 1999:90) against the provision made for disanalogy and disjunction in support of the idea of equiprimordiality is a major challenge for Gyekye. Gyekye appeals to a notion of rights found in "natural" as opposed to "voluntary" membership of society as exemplified by, for instance, social contract theory. According to Gyekye (1997:62) rights "belong primarily and irreducibly to the individual" and they exist "as part of the structure of a people's moral beliefs and values" (Gyekye, 1997:62). One particularly significant belief about what is valuable in the human being is that he has, by his very nature, "the qualities that will dispose ... [him] to function at his best in human society and realize his potentials to the full" (Gyekye, 1997:63). But this means that his rights "may not be asserted or insisted on with belligerency, for communal values such as generosity, compassion, reciprocities, and mutual sympathies may be considered more important than one's rights" (Gyekye, 1997:62).

The notion of the "equal moral standing" (Gyekye, 1997:41) of individuals-as-units and individuals-in-relation will shortly be qualified. I wish to show how Gyekye demonstrates its possibility through his concept of the interdependence of person and community. The individual, opines Gyekye (1997:37), is embedded in a set of necessary social relationships, but she is not wholly constituted by them. "Other things" (Gyekye, 1997:53), specifically "rationality, having a moral sense and capacity for virtue and, hence, for evaluating and making moral judgements" (Gyekye, 1997:53), which Gyekye (1997:53) regards as being "capable of choice" also play a role. The recognition of a "mental feature" (Gyekye, 1997:53) in the biology of the human species which is in principle independent of modification by the socio-cultural milieu, means that the individual-as-unit can "distance herself from ... [inherited values and practices], and thus be in a position to take a critical look at it" (Gyekye, 1997:52). "Self-assertion" (Gyekye, 1997:54) implies that the community is not invested with an "all-engulfing moral authority" (Gyekye, 1997:4748). And this leaves space for the individual to participate in the determination of her personhood and identity, which she does through the contribution she makes to her culture. "Human culture ... is shaped through the activities of ... individual human beings" (Gyekye, 1997:56). On the other hand sociality is a "natural" (Gyekye, 1997:39) feature of the human being - a feature which complements the inadequacy and insufficiency of the individual-as-unit in the sense that it supplies what is needed "for the realization of her potentials and basic needs" (Gyekye, 1997:38). The community "alone constitutes the contexts, the social or cultural space, in which the actualization of the potentials of the individual 
can take place" (Gyekye, 1997:39). Most importantly, the attainment of the excellences "definitive of full personhood" (Gyekye, 1997:49) is earned in the ethical arena. It is an individual's moral achievements that earns her the status of a person (Gyekye, 1997:51).

\subsection{Equiprimordiality qualified}

In as much as the self is an autonomous, assertive being the recognition of individual rights by communitarian morality is conceptually required (Gyekye, 1997:64), and in as much as sociality is a feature of the self there is justification for giving "equal attention to the other values of the community, all (or some) of which may occasionally be regarded as overriding" (Gyekye, 1997:65), a matter Gyekye (1997:65) believes "derives from the logic of the communitarian theory itself". Gyekye advances two main arguments reminiscent of those advanced by Will Kymlicka (1989). The community constitutes the context of identity. An agent "comes to know who she is in the context of relationships with others" (Gyekye, 1997:43). It also constitutes the context of choice: "the range of goals in life from which she can choose ... [are] the function of the [cultural] structure" (Gyekye, 1997:39). Members are morally responsible for the preservation of the cultural structure. The justification is twofold, deriving from the fact that the individual-as-unit is not self-sufficient (Gyekye, 1997:38), and from "our understanding of what social and solidaristic life requires" (Gyekye, 1997:67). It requires, opines Gyekye, "that each individual should work for the good of all" (Gyekye, 1997:67). Harmony, solidarity, mutual reciprocities and sympathies (Gyekye, 1997:65), being part of communitarian beliefs about what things have value, require "altruistically freighted" (Gyekye, 1997:67) motivations.

Gyekye (1997:67-69) contrasts this notion of rights with responsibilities. Rights are "a means of expressing an individual's talents, capacities and identity" (Gyekye, 1997:62). But rights do not necessarily imply corresponding obligations (Gyekye, 1997:68), so the responsibilities that individual members have towards the community (Gyekye, 1997:66) ${ }^{2}$ are not rights-claims of others - "they are not based on the recognition of others' rights" (Gyekye, 1997:69), but rather on our "moral responsiveness to ... [others'] needs" (Gyekye, 1997:68). Gyekye's "ethic of responsibility" (Gyekye, 1997:66) enjoins moderation: individuals should "not to be obsessed with insisting on their rights" (Gyekye, distress, the responsibility to show concern for the needs and welfare of others, the responsibility not to harm others, and so on" Generally, Gyekye has in mind "a caring attitude or conduct that one feels ... with respect to the well-being of ... other persons". 
Metanotionality, comprehensive democracy and left communitarian rights

1997:66) and he warns that an absence of sensitivity towards their responsibilities entitles the community to take steps which may involve "abridging individual rights" (Gyekye, 1997:65). Individual rights are "not absolute, though important" (Gyekye, 1997:65), but the preservation of a community's integrity is more important and is hence the reason why "the common good ... [may on appropriate occasions] justifiably trump individual rights" (Gyekye, 1997:66). Though the political community is not the locus of collective rights, the responsibilities citizens owe their community has "a status equal to that of rights" (Gyekye, 1997:67).

\subsection{The common good}

Individual rights, then, do not dilute individual commitment to cultural views which define their identity. They cannot without justifiable cause be "set at nought by the communal structure" (Gyekye, 1997:63), because they are an expression of the autonomy every human being needs "to function at his best in human society" (Gyekye, 1997:63). If so what constitutes the common good? Gyekye (1997:45) conceives of it as a "good ... which is essential for the ... basic functioning of the individual in human society", and identifies it with a set of goods which all individuals desire, a set of goods "that is essentially good for human beings as such [freedom, respect, dignity, security, and satisfaction]" (Gyekye, 1997:46). This notion is conceptually linked to "essentialism" (Gyekye, 1997:142), the view that "human life has certain basic defining features and, hence, certain basic human needs necessary for individuals if they are to function as human beings" (Gyekye, 1997:142). Gyekye (1997:273) sees these needs as part of "a core of common or universal ideas and values".

Though the common good is a substantive good, it leaves space for individual goods. Gyekye (1997:46) sees no "conceptual opposition" between the common good and individual goods, and no reactionary threat from the common interest to a "reevaluation of inherited values and practices" (Gyekye, 1997:53). Indeed, Gyekye believes that ideally there should be a balance between the common interest and individual goods, and that the political institutions of the state best maintains this balance. As Gyekye interprets this, political institutions cannot be neutral with respect to individually chosen goods: they should encourage otherregarding actions as valuable in themselves - thus serving as the locus for a normative point of view under which it is justifiable to regulate interpersonal interaction. The interpersonal realm of self-regarding actions is then not wholly selfregarding. In this realm individuals are free to act according to the range of options their cultures make available. But the principles by which they organize their private lives do not exactly mirror the principles by which the state acts on behalf of the collectivity. A 
Pieter Coetzee

strong strain of asymmetry in the sense Bird (1999:91) has in mind springs from this separation of private and public agency.

In an asymmetrical view ... the principles by which governments determine the appropriate action for the collectivity as a whole will bear no particular resemblance to those invoked by private agents as they lead and pursue their own lives and projects.

But Gyekye's disjunctions and disanalogies are not complete because a notion of the common good, a substantive one, may on appropriate occasion be overriding. The norm of the common good insinuates itself into individual self-reflection in a way which attenuates conceptions of particularity, difference and identity, thus shaping commitments to act in certain approved ways. Gyekye's state paternalism will be examined shortly. For the moment I wish to stress that asymmetry (Bird's term $1999: 91)$ is not fully realized. Gyekye (1997:45) says explicitly that the common good does not consist of, and cannot be derived from, "the goods or preferences of particular individuals" and that it is "not a surrogate for the sum of the different individual goods". Rather, the common good is a "substrate of commonly shared values and selfunderstandings" (Gyekye, 1997:46) which underpin organized human society. Its overridingness (when appropriate) is exactly that feature of his thinking which distinguishes him from Western individual liberal theorists (Gyekye, 1997:103).

\subsection{Persons-as-units and persons-in-relation: who is the locus of the value?}

What does it mean to say that the common good is overriding? Though, as I have maintained, asymmetry is not complete, individual rights are nevertheless genuine. Their existence mean that there are culturally endorsed rules and principles for individuals to formulate life plans which are not analogous to the rules and principles which specify how the collectivity should be ordered. Private and public agency, then, are disanalogous. Yet, in Gyekye, this does not entail that the collective plan cannot be accorded priority over individuals' plans (whenever appropriate), and, indeed, be overriding.

Gyekye's theory is in a crucial respect standardly communitarian. The arguments he advances regarding the cultural matrix as contexts of choice and identity is evidence for him that the collective interest overrides individual goods in cases of conflict. Gyekye (1997:40) formulates the foundation of this thesis as the claim that "the cultural community must be held as [ontologically] prior to the individual". In Gyekye the overriding normative force of community and the common good derives from this ontological priority. Yet the common good is that 
set of goods which all humans universally desire, and which are essential for the "basic functioning of the individual in human society" (Gyekye, $1997: 45)$. Now, one way of interpreting this view is to say that these are no goals or values which are independently or irreducibly collective. Indeed, the only goals which the collectivity pursues are those, as Bird (1999:51) points out, "whose value is fully reducible to individual interests and values". If this is correct, the cultural space I referred to above in which individual rights exist consists in the cultural constraint that, all other things being equal, collective aspirations are really individual interests and goals for which the collectivity provides the means of expression.

But, this interpretation misses an essential part of Gyekye's meaning. Gyekye wants to say that, in addition, there are forms of value which are irreducibly social. In particular the cultural matrix as provider of contexts of choice and identity makes possible the (self)understandings that render human action meaningful, and cannot, as Bird (1999:67) puts it, "be fully accounted for simply as a means to individual ends". Rather, they are independently valuable goods whose "'locus is a society'" independently, that is, of their utility to individuals. On this view, there are values assignable to societies as such, and they play a role in individuals' appraisals of how well or how badly they fare under their specific collective arrangements.

There is a useful way of showing how these two interpretations differ The effect of collective arrangements on the lives of individuals, and the state-of-affairs which make up these arrangements, should be distinguishable (Bird, 1999:69). There is a sense in which the set of goods which make up the common good - "freedom, respect, dignity, security and satisfaction" (Gyekye, 1997:46) - constitute a collective state-ofaffairs under which individuals live and which impacts on their lives. There is also a sense in which specific states of an individual is distinguishable from the collective state-of-affairs (Bird, 1999:69). Internal states of individuals are states "that subsist without any relation to anything outside the individual" (Bird, 1999:20). External states are "possible individual states relative to something outside" (Bird, 1999:20). Enjoying desire satisfaction, for instance, in being treated with respect in recognition of your dignity is not a collective state. But, now, as Bird (1999:69) points out, being treated with respect refers to a "collective state-of-affairs", in particular "a relation between an individual and the agents and institutions with which she is transacting". So is being treated with respect "an individual as opposed to a collective state-of-affairs"? (Bird, 1999:69). For Bird (1999:70) the matter turns on whether it is possible to draw a "meaningful distinction between the value of states of individuals and the value of states of the collectivity sui generis". If being 
treated with respect is an intrinsically valuable state of an individual, it follows, opines Bird (1999:70), that any collective pattern of interaction that instantiates it is an intrinsically valuable state. In this case the pattern of interaction carries value by itself; the question of its value is settled "without having to refer to any internal states of the individual" (Bird, 1999:71). But things turn out differently if we restrict the ascription of intrinsically valuable states to the internal states of individuals. If, then, we ascribe intrinsic value to the internal state of having our desires satisfied (as Gyekye in effect does by making desire-satisfaction a component good of the common good), and it turns out that being treated with respect results in desire-satisfaction for individuals (because such treatment recognizes their dignity qua humans), it follows, opines Bird (1999:20), that a collectivity in which individuals treat each other with respect will have value. However, according to Bird (1999:70) "this collective pattern of interaction will not be independently or irreducibly valuable ... It will inherit its value from that of the individual desires that are serviced by it".

On the one hand Gyekye (1997:101-106) writes as if he affirms the view that being treated with (equal) respect is valuable (only) as a means to the realization of valuable internal states, and that the collective arrangements in which such treatment is instantiated need not be valuable sui generis. Recognition as a person, and the moral satisfaction that this brings about, does not depend on an individual's "'ethnic badge' ... it is instead his moral worth or value, intrinsic to him as an individual human being, as well as his personal character that will determine or influence people's attitudes toward him" (Gyekye, 1997:104). On the other hand he writes as if he affirms the view that receiving recognition and satisfaction refers to an external state of the individual in as much as the appropriate treatment assumes a moral context in which one member stands in a particular relation to others, and that the value of the treatment resides in the relations that pertain among the individuals who constitute the community: "[Metanationality] ... recognizes the equal worth and dignity of every individual member of the community ... [but] does not necessarily hold that individual rights are invariably to be privileged over communal interests and goals" (Gyekye, 1997:103).

Thus the question arises whether Gyekye (1997:41) is serious about the claim that "the most satisfactory way to recognize the claims of the community and individuality is to ascribe to them the status of an equal moral standing? The matter of equiprimordality seems to arise from a preference for a specific kind of social organization, one in which the collective arrangements are such that the political institutions of the state are changed with respecting everyone's equal right to a private realm of choice and activity, yet is entitled to intervene when individuals' entitle- 
Metanotionality, comprehensive democracy and left communitarian rights

ments or claimed entitlements undermine the common interest. Gyekye interprets this intervention in a moral sense: the institutions of the political community are charged with instructing citizens in "competence to pursue the right thing" (Gyekye, 1997:55), i.e. adherence to his "ethic of responsibility". Now, intervention can only mean that any limitation placed on rights will be equally limited for all concerned in the interest of the well-being of the whole, not that some persons' lives are intrinsically more valuable than others and that others' prospects may be sacrificed to theirs. As I read Gyekye, everyone is equally entitled to the benefits of a private realm of social life; unequal entitlement would constitute a reason to reject the collective order which instantiates the inequality. On this reading of the relative value of individual rights and the common good, the asymmetry ascribed to Gyekye above is not complete because the private realm is not absolutely inviolable. In arguing for this collective order Gyekye is taking ultimate value to inhere in states of the collectivity as such.

Yet, I suspect that there is a deeper reason for Gyekye's preference. Gyekye sanctions a collective order which permits external states of the individual to be instantiated in a way Western liberals standardly reject. Gyekye's commitment to something like solidarity as a good in his conception of the common good, seems intrinsic to that good, such that granting others (equal) recognition as members can be, from his communitarian perspective, sufficient by itself to motivate a principled rejection of patterns of denial and marginalization. The available evidence suggest that the justification is the view that the individual human being is by herself inadequate and incomplete, dependent for her flourishing on a cultural matrix. The self is a person only as socially embedded individual. Personhood is content-full, dependent on a thick conception of the notion of "the social" - one in which, as Bird (1999:79) puts it "the hidden hand of the community' is given free rein to paint a more colorful, less rigidly modernist, social landscape of customs, shared histories, cultural understandings and moral traditions".

\section{Domination, resistance and revision}

\subsection{Welfare paternalism and the distribution of liberty}

Gyekye is arguing that equiprimordiality is compatible with a communitarian preference for a thick conception of the social and a maximal conception of the competence of the state. Equiprimordiality creates a private space for individual rights founded on the idea that there is a set of human needs, common to all humanity, which create legitimate expectations of fulfilment in society. This set is the core of universal values needed to ensure human flourishing or well-being in any society. 
In this private space $^{3}$ individuals are morally immune from interference by others, though not from paternalistic interference by the state. The promotion of valuable social goals can, when necessary, override individual rights, though, as indicated above, if rights are restricted, the restriction applies equally 4 . It is permissible to restrict rights if the restriction is necessary to secure a desired outcome, one which benefits individuals equally. I shall call this the equal restriction principle (ERP) ${ }^{5}$

I take it that ERP correctly represents Gyekye's view. It represents a decisive break with African tradition (Eze,1997:173). ERP implies that individuals are not entirely free to specify the private sphere as they please. Individual action is subject to correction by the state if it interferes with the realization of the common good, with this proviso 6 that a restriction on one is a restriction on all, so that the good of some are not (unjustly) sacrificed in order to promote the (claimed) good of others. The realization of the common good may be hindered if fundamental rights, i.e. rights based on universal human needs - to freedom, respect, dignity, security and satisfaction (Gyekye, 1997:46) - are obstructed. These rights can be obstructed by individual action, for instance, through coercion, which denies to some an equal entitlement to liberty and security or through non-recognition, which denies to some an equal entitlement to respect and dignity. In these cases remedial interference

Young (1990:120) argues that the distinction between the private and the public domains need not be a "social division" - each with "different kinds of institutions, activities, and human attributes". It is not clear whether Gyekye has a social division in mind His concept of a heterogeneous public is much like Young's in conforming to two principles: "no persons, actions, or aspects of a person's life should be forced into privacy ... and ... no social institution or practices should be excluded a prion from being a proper subject for public discussion and expression".

4 Rhoda (1990:179) thinks that "African scholars who advocate a distinct African concept of human rights seem to be [preoccupied with] the right of the individual to separate him - (or, as noted, frequently her-) self from the group, not to assert claims against the state". Though Gyekye is advancing an African conception through his notion of the equiprimordiality of person and community, individual rights are, for him, claims individuals assert against the state They assert their rights claims as individuals, but their rights protect the non-ethnic communocultural identifying groups to which they belong

$5 \quad$ ERP represents a decisive break with tradition - what Eze (1997:173) scathingly calls Wiredu's "retum to the source" strategy of doing philosophy. Meyerson (1997:xxiii) discusses a similar limitation clause - Section $36(1)$ - in the new South African constitution.

6 The point at issue here is one defined by Lomasky (1987:19). "Rights are side constraints that preclude the sacrifice of one individual for the sake of another in order to maximize impersonal value" 
Metanotionality, comprehensive democracy and left communitarian rights

by the state is restricted to restoring equality, and may not exceed the side constraints (Lomasky's term - 1987:19) which rights generate, i.e., interference may not frustrate the expected satisfaction of some for the sake of some optimal sum of impersonal satisfactions. So, though not every claim to a right is inviolable, the equal entitlement of everyone to basic rights are. Though the notion of liberty is inseparably connected to an equality of access to the other goods that constitute the common good, to secure the desired equality it is necessary that liberty be restricted, and this Gyekye attempts to effect by proposing a selfimposed restraint. Individuals "may not be obsessed with insisting on their rights, knowing that insistence on their rights could divert attention from responsibilities that they, as members of the communitarian society, should strongly feel they have towards other members" (Gyekye, 1997:66). In Gyekye's view an equal distribution of basic rights is realized if individuals act with restraint, which they have good reason to do, opines Gyekye, because they have good reason to preserve the cultural structure that provides their contexts of identity and choice.

In Gyekye liberty and restraint are conceptually connected as we shall shortly see. Individuals have an area of moral space - the private domain - immune from the interference of others, but within this space they are not fully free to do as they wish because the state may interfere to bring about their well-being. They have a higher-order interest in being free; freedom is of such value that the state sets "external limits" (Bird's term $1999: 116)$ to the violation of liberty. These limits apply to violations which may result from the intentional action of an agent, such that she can be held morally responsible for the harm done to others, and also violations which result from state action itself, such as sacrificing some person's rights for the sake of a greater overall utility. The harm done to others are the consequence of coercions. Bird, following Nozick (1972) and Raz (1986), treats coercive obstacles as "obstacles caused by human action". Among this class of obstacles Bird (1999:117) distinguishes interferences. An obstacle becomes an interference "when it hinders, thwarts or meddles with some activity or project which an agent chooses to engage in, or in which an agent has some particular interest or whose continued availability is of real concern to the relevant agent". This category of interference is critical. Being compelled to submit to the dictates of compulsory education for all children below a certain age counts as a coercion but not an interference. Compelling all property owners to sell their property ${ }^{7}$ and donate the proceeds to a fund for starving children interferes with the institution of property rights which 
has significant value for many people, and this counts as an interference and a coercion.

In Gyekye no one has the freedom to renege on the ethic of responsibility i.e. on actions and behaviours "conducive to the promotion of the well-being of others" (Gyekye, 1999:50). Individuals act morally correctly, and thus are worthy of being accorded respect, when they act as autonomous agents, i.e. when they freely submit to the required restraint. But this means that they accept and internalize the authority of justified communally based decisions which are initially external to themselves. At play here is a concept of liberty which equates liberty with a self-restraining motivational capacity. State action aimed at inculcating the desired restraint may, in view of the connection between liberty and restraint, be seen not only as compatible with liberty but also as education for the realization of liberty. The liberty at issue here is positive liberty, the freedom to do things rather than the freedom from interference or coercion by others. The notion of "liberty to" is the "capacity building" conception favoured by Gyekye. It is the key, opines Gyekye (1997:141), to integrating "political liberty (individual freedom) and social welfare" in a sociopolitical framework which gives concrete expression to the idea of "social and political equality" (Gyekye, 1997:141). Gyekye (1997:142) advocates a "comprehensive conception of democracy" which will give recognition to social and economic rights, on par with political rights, as necessary conditions of the functioning of humans in society (Gyekye, 1997:142)8. "Political rights cannot be divorced from economic well-being: a person may be free politically and yet not free to pursue and realize his or her chosen purposes in life because the necessary conditions are denied him or her" (Gyekye, 1997:193).

All citizens must have equal opportunity to influence political decisions, yet the capacity to make effective use of such opportunities vary widely in proportion to differences in wealth and social standing (Gyekye, 1997:142-143). Liberty deficits are best righted by institutions which establish a minimum threshold for equality regarded as adequate for public functioning and below which citizens cannot reasonably be expected to influence the outcome of deliberation. The minimum threshold must be guaranteed as a way of protecting the weak against the strong and this requires restraint to ensure that the weak are not

8 For a similar view see Ryan (1989:117). According to Ryan (1989:162) the right to equal treatment is inseparable from its institutional context and the "interrelational character of social wealth". The doctrine of rights should be understood as "a doctrine of exercisable rights". 
Metanationality, comprehensive democracy and left communitarian rights

alienated from the capacity building conditions of choice ${ }^{9}$. The equal entitlement to economic and social rights - "food, shelter, security, goodwill, friendship, and self-respect" (Gyekye, 1997:48) introduces a welfarist stance into Gyekye's paternalism. As I read Gyekye, he attempts to maintain a reciprocal balance between responsibility and liberty. Clearly, the attempt to secure equal access to political rights by guaranteeing economic and social rights restricts liberty in the interests of equality, yet it promotes equal liberties overall, and this is in keeping with the ERP. It is permissible to restrict liberty but not in excess of what is required to secure the equal liberty of citizens. So the side constraints of the right to liberty are not exceeded.

In Gyekye the "internal boundaries" (Bird, 1999:34) or "core elements" (Bird, 1999:32) within the sphere of private action towards which individuals are constrained to act in particular ways, are significant; the line dividing private and public space is then not absolute, yet there are "external limits" (Bird, 1999:32) to individual action defined by rights specifying equal liberties for all. To capture Gyekye's meaning it is necessary to add that the dividing line seems to be negotiable for individuals. What they treat as private seems to be a matter open to choice. If correct, this accords with Young's view (1990:120) who argues that the distinction between the private and the public domains need not be a "social division", each with "different kinds of institutions, activities, and human attributes".

The comprehensive theory of democracy, coupled as it is to a philosophy of restraint, is intended to alter individuals' attitudes to their interests so that the requirements of equality are met. Because they have a higher order interest in solidarity, they will be less inclined to pursue interests incompatible with the equal moral status of others. The source of appropriate moral relations between individuals, then, is to be found in the natural sociality of individuals, a locus within them which disposes them to submit to restraint. Restraint maintains balance between the private and public realms and determines to some extent where the line should be drawn. Indeed, where it is drawn depends on how much restraint they are willing to accept, i.e. it depends on internal relationships between individuals' private and public identities. Intrapersonal relations and interpersonal ones are reciprocally connected through the willingness to submit to restraint. This means that the requirements of liberty and equality are interlinked. Moral properties, on this view, are associative - a pattern of relations between persons - to

9

Bohman (1997) argues for much the same concept 
the extent that persons suppress interests that might lead them to act in ways inconsistent with the requirements of solidarity and the egalitarian relations of dignity and respect. (I shall qualify this view somewhat later) The requirements of solidarity and the egalitarian relations of dignity and respect define an area in which negative liberties - freedoms from interference by others, are exercised. The existence of this area of negative freedom makes possible the exercise of positive liberties, freedoms to do things, in ways consistent with restraint. Positive liberty is the capacity building conception of freedom aimed at educating individuals to becoming autonomous agents. Autonomy, then, consists in freedom to do things within the constraints determined by the requirements of solidarity and the egalitarian relations of dignity and respect.

But persons also act on their own behalf. Intrapersonal relations determine normative points of view from within which individuals justify acting in particular ways towards themselves. In Gyekye two central moral notions, those of positive liberty and satisfaction belong to this category. The principles by which individuals act on their own behalf, and those by which the political institutions of the state act to protect the private realm, are different but connected through the domain of morality which covers the intra- and interpersonal relations. To the extent that these principles are connected, to that extent Gyekye advances a symmetrical conception of the relation between individual and public agency. To the extent that they are different, to that extent an asymmetrical conception becomes apparent. The presence of some aspects of symmetry means that asymmetry in Gyekye is not complete. His theory is a version of communitarianism combined with elements of liberal individualism, which makes him a left communitarian.

In summing up: Liberty is secured by an interactive combination of individual and public agency. Ultimately, Gyekye identifies freedom with the willingness to submit to restraint, and it is in virtue of this capacity that individuals gain moral standing as individuals, and as good citizens. It is legitimate for the state to interfere with liberty to secure the equal entitlement of all to the exercise of rights in the public domain. How much interference is tolerated is a function of what individuals consent to, given their commitment to protect the common interest. Public coercion is legitimate to prevent coercive interferences by other agents; public interference is legitimate to secure equality of participation in the public domain. Public interference is paternalistic but remedial, aimed at capacity building. These interferences structure a range of opportunities and choices which may restrict the options available to some agent in some way. Being prevented by such structuring from pursuing some activity or project in which some agent has an interest counts as an obstacle, though not a coercive one. The obstacle is an interference for it 
Metanationality, comprehensive democracy and left communitarian rights

prevents realization of something valuable to someone that may have been attainable in some different collective organization.

\subsection{Cultural oppression and moral revision}

The way in which Gyekye's preferred form of collective organization structures the range of opportunities and choices available to an agent allows only talk of an estimate of the extent to which an agent is free ${ }^{10}$. Berlin (1969:xxxiv-xl) defines negative freedom as the "absence of [culpable] obstacles to possible choices and activities", which, when coupled with the thesis that culpable obstacles are coercions and coercions are unacceptable infractions of liberty (Berlin, 1969:122), implies a view of "individual inviolability" (Bird,1999:115) of the kind Gyekye's permissible interferences can accommodate. "Individual inviolability" is the strong thesis that the only legitimate interferences with individual liberty are those which are necessary to guarantee the inviolable and equal entitlement of each to "exercise their own capacity for moral autonomy" (Bird's rendition of Kant's base line - 1999:113), and to "personal and propriety security" (Bird's rendition of Mill's base line - 1999:129). Both exclude any permissible right to structure individuals' opportunities and choices for their own benefit, or to "educate them into autonomy" (Bird, 1999:133). Gyekye's incomplete asymmetry stops short of the inviolability criterion of these theses: a public ethos does intrude upon the private sphere of activity in the sense that it may prevent the realization of some interests which some agents may in fact have. Incomplete asymmetry allows for this limited penetration of paternalism. It also allows internal boundaries to the zone of morally permissible actions alongside external ones. This feature of Gyekye's theory, in particular the reciprocal balance between these boundaries, I think, is the great strength of Gyekye's theory.

How is the boundary drawn? I need to give a sense of the reciprocal balance Gyekye requires between internal and external limitations to liberty infractions. A culpable infraction of liberty, one for which the transgressor may be held morally responsible, counts as a harm. Meyerson (1997:15), following Nagel (1991), invokes the principle of "reasonable unanimity" to establish consensual grounds for the

10 Waldron (1995:109) concurs "To preserve a culture - to insist that it must be secure come what may - is to insulate it from the very forces and tendencies that allow it to operate in a context of genuine choice ... The possibility of erosion of allegiance, or of the need to compromise a culture beyond all recognition in order to retain allegiance and prevent mass exodus, is the key to cultural evaluation. It is what cultures do, under pressure, as contexts of genuine choice". 
legitimacy of liberty limitations. Nagel asks what limitations citizens would agree to when the conditions under which they grant their assent were fair, i.e. when morally irrelevant considerations such as superior force, the de facto bargaining power of their economic and social status, greater numbers and so on were not allowed to affect the outcome of deliberations. If participants were "fairly situated reasonable people", i.e. people "who relate to each other as possessors of equal moral status" (Meyerson, 1997:15)11 they would submit to "public reasons" (Meyerson, 1997:17), "reasons that, acknowledging the fact of everyone's equal status, speak to everyone's perspective. This means ... everybody's reasons". Under these conditions state intervention to outlaw an unorthodox religion would count as unfair. The state "may not seek to prevent a harm which would not be suffered in the absence of an intractably disputed belief that the conduct in question is wrong from the religious point of view. But this is exactly what they seek to do when they interfere with religious freedom on the sectarian grounds that a certain religion is intrinsically more or less worthy of being followed, offering justification that ... is a justification only for those who hold certain intractably contested religious beliefs" (Meyerson, 1997:19).

But, when the state prohibits the followers of the unorthodox religion from making human sacrifices at their ceremonies "the prohibition of the conduct aims at the prevention of a harm - involuntary loss of human life - whose status as such can be defended in terms to which any reasonable person ... would accord at least some weight" (Meyerson, 1997:19). The public reasons requirement is the threshold test set by ERP. When the requirement is fulfilled, the threshold of justification is passed. "Justificatory neutrality" (Meyerson, 1997:21) is thereby maintained, i.e. the state is thereby disabled from enforcing intractably disputed beliefs, and so to recognize the "indissoluble plurality of ... [the] different perspectives" (Meyerson, 1997:19 citing Michelman, 1988: 1518) that make up the public domain.

\subsubsection{Weak cultural unity}

Gyekye's agents have a higher order interest in the preservation of the cultural matrix. It is part of permissible state intervention in the lives of citizens to secure the matrix through educational policies which educate citizens into endorsing the public ethos. The public ethos is a feature of the national identity of the nation state, of "the principles of collective

11 The perspective in question need not be independent of that made available by the cultural matrix. Gyekye interprets the injunction to grant equal dignity and respect as culturally anchored among his Akan people. 
Metanotionality, comprehensive democracy and left communitarian rights

belonging ... the set of characteristics by which a nation can collectively define itself and be distinctly recognized" (Gyekye, 1997:113). In the multicultural states of Africa the idea of a national identity should be understood in terms of metanationality" (Gyekye, 1997:96) as a metanational identity consisting of a synthesis of communocultural identities, developed in a "shared" environment (Gyekye, 1997:113) as opposed to a monolithic cultural environment in which the individual and not the ethnic group to which she belongs, is the "primary unit" (Gyekye, 1997: 96). The metanational state is then a "state composed primarily of individuals who belong to cultural communities" (Gyekye, 1997:106). Communocultural identities coexist with the metanational identity which lies anchored in a weakly unified cultural life ${ }^{12}$, one which members of the component communocultural groups can identify with without engendering conflict with their natural (communocultural) identities. Gyekye (1997:107) sees the weakly unified culture as a "participatory culture", a second-tier of shared meanings by which members understand themselves and interpret their experiences, a political culture in the process of evolution which accompanies the development of a political identity (Gyekye, 1997:81).

How does Gyekye propose to construct the metanational state? The mechanism is education. In the attempt to pursue metanationality, "ethnic identities and their concomitant primary allegiances will have to be ... deemphasized" (Gyekye, 1997:83), and "primary allegiances" will have to be transferred from the ethnocultural community to the state, that is, from the parts to the whole" (Gyekye, 1997:84). The upshot is that distinct, particularistic forms of identification would have to, through retraining and re-education, lose some of their meanings to the evolving, new sociopolitical dispensation. (Gyekye, 1997:87) ${ }^{\mathbf{1 3}}$ "De-emphasis" (Gyekye, $1997: 88$ ) of particularistic identities will encourage the growth of "horizontal relationships" (Gyekye, 1997:89) as a complement to the vertical ones, the "intra-ethnic relationships" (Gyekye, 1997:90). The "politics of participation" (Gyekye, 1997:89) must redistribute the material as well as the moral goods of society. "The allocation of development resources

12 The strong conception is the notion understood as an "ethnocultural community" (Gyekye, 1997:78-81)

13 Waldron (1995:109) points to an uncertainty factor that arises in assimilationist contexts. "We cannot guarantee at the same time the integrity of a given community and say that its culture (or the fate of its culture) can tell people about the value and viability of this particular way of life Either people leam about value from the dynamics of their culture and its interactions with others or their culture can operate for them at most as a museum display on which they can pride themselves ... There is something artificial about a commitment to preserve minority cultures". 
and projects must be horizontal, spread across the board", with no one district or region - and hence no one ethnocultural community left in limbo. (Gyekye, 1997:90). Privileging of one ethnocultural community over another, deriving from cultural dominance, will have to be countered by "the due consideration and respect that ought to be given to the dignity of every individual member of the state" (Gyekye, 1997:91)

Gyekye's politics of participation is akin to Taylor's (1994) politics of recognition in that "component groups would consider themselves culturally and politically equal, even though they may not be really equal" (Gyekye, 1997:92). The presumption of equality would have to be compromised in one respect, which will privilege one group or some linguistically related group, viz. the choice of a national language. "It would be necessary for the state to involve itself in deciding which language (or, languages) will be given official support" (Gyekye, 1997:93). But privileging would have to be played with due recognition to the politics of difference ${ }^{14}$ in Young's (1990) sense, i.e. without falling victim to the "group-neutral human capacity for self-making" (Young, 1990:165) a fallacy which denies group difference as a category ${ }^{15}$ of liberation. From an individual's perspective the emergence of "multiple identities" (Gyekye, 1997:95) weakens her allegiance to particular groups, but does not eradicate her group membership; it renders ethnocultural borders less well-defined, but does not render group membeship undesirable; her "multidimensional cultural identities" (Gyekye, 1997:104) enable her to elevate one or more language(s) to the level of official language(s) without compromise to her natural communocultural group, ${ }^{16}$ which remains as one basis of her identity as individual17 (Gyekye, 1997:105).

14 Actually Taylor also recognizes the need to play the politics of difference. Van der Merwe (1999:322) sums up: "the current demand for recognition of cultural differences ... involves an internalizing of the ideals of autonomy and authenticity and it leads to a bifurcation in the 'politics of equal recognition' between on the one hand the demand for the recognition of equal rights (whatever the differences) and on the other hand the demand for the equal recognition of the differences themselves, in other words of that which is experienced as the uniquely own. The former, which Taylor calls the 'politics of difference' and which I describe as the appropriation of the right to difference. cashes in on the credit of a universal recognition of equal rights, and changes it into the hard currency of recognition of the right to particular differences"

15 See Young (1990:156-191)

16 Gyekye prefers to use the term communocultural. See his distinction between ethnic and communocultural groups in Gyekye (1997:77-87). 'An 'ethnic' group is in fact a cultural community, comprising people between whom there may or may not be kinship bonds" (Gyekye, 1997:105). 


\subsubsection{The case against oppression}

\subsubsection{Cultural oppression}

Kernohan (1998:12-13) defines oppressive practices as "a set of actions taken not by a single person, but instead by different people each time which are harmful either individually or collectively or both". Job discrimination, for instance, qualifies as a practice of social oppression. So does the transmission of false beliefs about values, such as the belief in the unequal moral worth of persons prevalent in societies which practise gender discrimination ${ }^{18}$. Kernohan (1998:12) treats oppressive practices as accumulative harms, which manifest as internalized negative self-images caused and sustained by the culture in which the agent lives.

Cultural oppression is a form of power (Kernohan, 1998:14). Kernohan (1998:15), citing Galbraith (1983:25-26) sees the connection in the concept of implicit conditioned power.

Only a part of the subordination of women was achieved by explicit instruction - explicit conditioning. Much and almost certainly more was (and is) achieved by the simple acceptance of what the community and culture have long thought right and virtuous ... This is implicit conditioning, a powerful force.

Young (1992:180) calls the implicit conditioning power of a culture "structural or systemic" oppression which Kernohan (1998:17) compares to Foucault's (1982:781) notion of "a form of power which makes individual subjects". Foucault recognizes "two meanings of the word 'subject': subject to someone else by control and dependence, and tied to his own identity by a conscience or self-knowledge. Both meanings suggest a form of power which subjugates and makes subject to". Kernohan, like Galbraith and Young, is concerned with the latter. In the relevant Foucaultian sense tying people "to the conception of the good which form their own identities ... subjects ... them to their culture" (Kernohan, 1998:17). Subjugation in this sense, however, is not necessarily harmful. Subjugation is harmful if, for any individual, it interferes with "the very process of forming a conception of the good" (Kernohan, 1998:26), in knowing her good or in implementing her conception of the good, which is a harm to self-respect. If she is coerced

17 "It is possible for groups of people to speak the same language while some features of their cultures differ, notwithstanding the existence of many other features that may be similar" (Gyekye, 1997:94).

Both examples are borrowed from Kernohan (1998:12-13). 
(for instance, by state intervention) "into leading a life that is less good than she could have led without the intervention, then ... coercion will have harmed her highest order interest [in leading as good a life as possible]" (Kernohan,1998:30). But people's lives would often go better "if they pursued some other good. If the state coerced them into living their lives in a better way, what would be wrong with that?" (Kernohan, 1998:30).

Dworkin (1990:50), citing Locke (see Locke, 1991:33), requires an affirmation of the 'endorsement constraint'. "A person's endorsement of a conception of the good is necessary for it to be a good for her" (Kernohan, 1998:30). Endorsement, in Dworkin's sense, is only necessary for the ascription of value; it does not entail that decisions are incorrigible. An agent may still be mistaken in the sense in which Sisyphus was mistaken (see Kernohan, 1999:31-32). To avoid this Dworkin requires the "authenticity constraint", which, in addition to making the agent authorative over her conception of the good, also guards against deception, so that her endorsement is truly constitutive of who she believes herself to be, after due consideration of the merit of the good in a critical, reflective way (as Dworkin, 1989:486 demands). The authenticity constraint presupposes, as Kernohan (1999:33) makes clear, a "knowledge constraint": her "highest-order interest is in coming to know what is best for her and then being able to implement it". In an important sense, knowing what is best for her is having true beliefs about her good, one's she can justify to others (Kernohan, 1998:34-35). The sense at issue concerns the need for revisability: her good must be revisable in the sense of being responsive to justifying reasons. To protect her from harm to her highest-order interest in leading the best life possible, we have to protect her highest-order interest in knowing what is best for herself (Kernohan, 1998:36).

How is this higher order interest best protected? Mill (1991:54-55) advises virtual untrammeled freedom of expression 19. Dworkin (1990: 50) believes that coercing someone to act in accordance with some conception of the good she does not endorse, cannot make her life go better for her. Gyekye (1997), along with communitarians like Sandel (1982:152) emphasizes capacity building - particularly a capacity for agency, which requires positive liberty and self-knowledge. Capacity building, in the relevant sense, is done as subjects of a cultural matrix, through a process of moral socialization. "We can know a good in common that we cannot know alone" (Sandel,1982:183). Capacity

19 I shall not discus Mill's view at this point because it is not directly relevant here 
building, in Gyekye, underwrites the need to protect the cultural context within which the common good is realized - the values of "freedom, respect, dignity, security and satisfaction" (Gyekye, 1997:46). The second-tier of shared meanings and understandings which constitute the socio-political identity of the state - as distinct from the communocultural groups which make it up - underwrite these values as rights to which individuals bear title, but without falling victim to a fallacy Young (1990: 165) draws attention to - the so-called "group-neutral human capacity for self-making".

\subsubsection{Second-tier solidarity}

Gyekye's notion of a weakly unified political culture consist of a secondtier $^{20}$ of shared meanings and understandings, which is in effect a second-tier solidarity. It is now time to give a sense to what the notion entails. Second-tier solidarity is a force for socio-political integration. It can accommodate the group consciousness of communocultural matrices in ways which negates difference as otherness, "exclusive opposition" (Young, 1990:171), and affirms it as "specificity, variation, heterogeneity" (Young, 1990:171). Thus understood, difference is conceived as relational, which relativizes the positions of various groups, priviledged and oppressed, and understanding of difference is contextualized, which undermines essentialist assumptions about identity (Young, 1990:171). Relativization and contextualization of the meaning of group identity leads to its revision: "what makes a group a group is a social process of interaction and differentiation in which ... people come to have a particular affinity for others" (Young, 1990:172). Membership across group boundaries then becomes possible: membership is "the affirmation of that affinity by other members of the group, and the attribution of membership in that group by persons identifying with other groups" (Young, 1990:172), making possible "overlapping experiences" (Young, 1990:171) between groups. Groups, then, share in the specificity of other groups. Second-tier solidarity arises from multiple group

20 Gyekye's distinction between first and second-tier solidarity corresponds to Van der Merwe's (1999:316) distinction between thin and thick multicultural societies. "With thin multiculturalism is meant societies in which the cultural differences which are claimed as rights are embedded in a greater (political) culture, a liberal democratic culture or a culture of universal human rights in which a consensus exists about the right to differences as, for example, has been the case in Belgium until recently. Thick multicultural societies refers to societies, like israel, wherein certain of the cultural differences which are claimed as rights, undermine a general acknowledgement of the right to difference, for example, when what is demanded is the right to a nondemocratic political system, or the prohibition of religious freedom, freedom of speech and so forth" 
identifications, which allows group differences to cut across social groups, i.e. collectives which have affinity with one another because of a set of practices or way of life and which differentiate themselves from other groups according to these cultural forms (Young, 1990:186). Difference, then is a "side-by-side particularity neither reducible to [essentialist] identity nor completely other" (Young, 1990:238-239).

In this public realm generality - the perspective of a general standpoint attained through consensus (Gyekye, 1997:130-131, 139-141), is not attained by the exclusion of particularity. Particularity should be captured in decision-making procedures - "as far as is feasible" (Gyekye, 1997: 139), i.e. the "supermajority" (Gyekye, 1997:140) of consensus must be given preference over the simple majority of majoritarian systems to prevent a situation from arising in which "the interest of minority groups may eternally be ignored or not adequately protected" (Gyekye, 1997: 139). Rather, generality is a function of real participatory structures in which content-full persons assert their perspectives on social issues within consensually driven institutions that encourage the representation of their distinct voices. The need for consensually driven institutions is given by the social ideal of solidarity (Gyekye's "supermajority"), and by the need to prevent dominant groups from articulating the "common good" in terms influenced by their particular perspectives and interests (Gyekye, 1997:130-131).

Consensus is, of course, the cement of social integration in Gyekye's order of things. It represents, as Eze (1997:313) points out, a "return to the source" move, an attempt to order morality and politics in Africa along traditional lines. Gyekye and Wiredu are here in accord. Wiredu (1996:173) refers to the traditional ordering mechanism as a "culture of consensus" - a "deference to the common good" not inconsistent with dissent. A return to tradition would inspire a modern indigenous form of African consensual democracy, connecting post-colonial Africa with its pre-colonial past. The advantages of this would be twofold: a sharing with every constituency the exercise of governing power, and a substantive representation for even the smallest constituency. This represents one answer to the all important question: "How to safeguard the rights of the minority parties who did not 'win' the election" (Eze, 1997:313 - paraphrasing Wiredu).

Now, the strength of consensus, as presented by Gyekye and Wiredu, boils down to the "will to consensus", which, as Eze (1997:317) notes, may be interpreted in two ways: the idea that "human beings have the ability eventually to cut through their differences to the rock bottom identity of interest "through rational discussions" in either a belief in the power of reason or an African belief in the power of their belief "in a 
shared and common past and future" that leads them to pursue reason as a means of realizing the favoured shared life-form. Eze (1997:318319) thinks the latter weighs heavily with Gyekye and Wiredu. They tend to conflate the "conflictual" with the "irrational" and the "rational" with the "consensual", and this conflation is clearly a cultural bias for harmony over conflict, i.e. for a politics of the common good over a politics of difference and individualism. There is not "much self-evident truth" (Eze, 1997:320) in the notion that the favoured ordering mechanism of Akan society is a universal preference, one that can be teased from some analysis of the human condition.

Eze (1997:320-321), agreeing with Gyekye (1997:101-106, 133-140), argues that the mixed "multi-party" alternative to democracy (mixed in the sense of containing consensual and majoritarian elements) is a postcolonial response to "conflicts that necessarily arise from the necessarily competitive nature of individuated identities and desires" (Eze, 1997: 320). Wiredu's idea of "agreed actions without agreed notions" cannot be the goal of multi-party democracy, "but only one of its [albeit privileged] moments" (Eze, 1997:320), "the initial, formal agreement to play by a set of rules that allows ... respect of dissent as much as its oppositen (Eze, 1997:321). A truly democratic (political) culture is one that "reconciles both centripetal and centrifugal political forces" (Eze, 1997:321), i.e. one which balances considerations of the public good against individuated disagreements and oppositional activities, understanding itself as "a market place of competing - not just consenting or consensing - ideas" (Eze, 1997:321). Modernity calls for a rights-based state, one which either upholds individuals rights as trumps, or finds some reconciliation between individuals and groups as right-bearers, as Gyekye attempts to do.

Second-tier solidarity, then, pursues the ideal of a heterogeneous public. The interplay between internal and external limits to the violation of liberty determines a certain conception of the public realm: it is not a unity transcending group differences but rather a unity-in-diversity; the differences needed for identity construction remain unassimilated at the level of the social group in the sense in which social groups are first-tier solidarity groups. But the multi-dimensional aspect of membership of first-tier identifying groups, and the concomitant multidimensional identity construction which this makes possible, give rise to second-tier solidarity. Private life, in contradistinction to public life, then becomes a part of a person's life which she chooses - with justification - to withdraw from 
public view (Young, 1990:119-120) ${ }^{21}$. Even if Gyekye's distinction between the private and the public realms is a social distinction, then this option is possible within one part - the private part - of the division. This too is a consequence of the internal-external tensions that arise from the need to limit liberty.

The picture of private and public agency that emerges here is possible, Gyekye thinks, if the state intervenes in the interest of capacity building. Capacity building is a procedure for empowerment. And empowerment, in turn, is a procedure for ensuring effective agency, understood as a level of participation at which citizens can reasonably expect to influence the outcomes of deliberation. Participation at this level, the minimum of public agency, is a necessary condition of the possibility of moral revision. There are two sufficient conditions, one relating to history, the other to individual prowess.

Cultural contacts may lead an individual to think and act outside his history 22 ... The historical emergence of moral visionaries or idealists in societies is an eloquent testimony that the moral hands of (some) individuals are not tied by the communal structure (Gyekye, 1997:60)

Gyekye (1997), along with Kernohan (1998) and Ryan (1989), proposes a strategy under which the state uses its power to advocate reform, challenge false beliefs about morality, and ensure that no one falls below the minimum level required for effective political participation. Gyekye (1997:140-141) sees this strategy as entailed by his "comprehensive conception of democracy". "The comprehensive conception of democracy will be the kind that is likely to espouse the politics of the common good, the politics that aims at promoting a set of fundamental goods or interests held as essential to basic human flourishing" (Gyekye, 1997:142)

Gyekye's paternalism preempts some options by structuring particular ranges of choice. This may prevent some people from "influencing the shared moral environment" (Dworkin, 1993:41) because the structures needed for the realizations of their goods are not available. This, however, does not mean that they cannot create those structures by 1990:173). In this sense the social and identifying groups to which individuals belong are submerged in the public domain.

22 Bernstein (1991:91) offers an explanation of the possibility of transacculturated moral truth, in the "core"-sense Gyekye has in mind. He says: "a given tradition may contingently tum out to be rationally superior to all its rivals "as a consequence of the power of the culture which spi-":ls the tradition, or some other contingent reason". 
Metanationality, comprehensive democracy and lett communitarian rights

exploiting the possibilities of revision. The challenges faced by these people may be more arduous than others who are content with their moral environment, but this does not deny them equality of access to shaping that environment; formally, equality of access is denied to noone, but there may be substantive differences, differences in material well-being, which give some an advantage over others, and which Gyekye attempts to combat by guaranteeing a minimum to ensure effective participation. Gyekye's position in this regard is comparable to Ryan's "exercisable rights" (Ryan,1989:162) ${ }^{23}$. So Gyekye combines a laissez-faire strategy (Kernohan, 1998:91) which confines state intervention to securing the basic conditions of equal basic liberties and material equality (favoured by Dworkin, 1990 and Kymlicka, 1989), with the "advocacy" strategy (Kernohan, 1998:91) which entitles the state to structure the moral-political domain indirectly through its capacity building programmes.

\section{From Ghana with love}

It is instructive to note that the new South African constitution is firmly committed to the liberal concept of individual rights and that this commitment secures for many people a route from tribally grounded identities to wider collective identities, particularly a South African identity. Individual rights are also of critical importance in making space for choice in the issue of personal identity in that they serve as a public affirmation of the right to choose one's membership of identifying groups. The idea that a choice is possible is in part a function of the growing consciousness that it is possible to separate one's individual identity from one's social identity. But while affirming the right to choose, the constitution fails to make positive provision for this right to be exercised. It fails to equip the state with the power legitimately to promote a culture of pluralism, thus remaining passive in an area where active initiatives are needed. Such initiatives are valuable to offset some of the negative consequences of enforced membership at a time when it is becoming increasingly obvious that the monocultural (i.e. monoracial) identifications to which people were subjected on grounds of birth during the apartheid era underwrote not only a false view of the self, but also of the nature and value of identifying groups. The constitution remains silent on the issue of "groups" or "communities" (no doubt for fear of the "neoapartheid" label), but in doing so disables the cause of democratic pluralism.

23 See Ryan (1989:162). Like Gyekye, Ryan advocates economic and social rights as backup rights to ensure effective utilization of political rights. 
For South Africa three important lessons are available.

\section{- The relationship between first- and second-tier solidarity}

The first concerns the relationship between first- and second-tier solidarity. At second-tier solidarity citizens are not differentiated. But individuals' first-tier communocultural groups, the groups with whom they identify, are morally significant and therefore differentiated, and this is because membership of these groups is the source of loyalty to the political institutions which impact on their lives at the level of second-tier solidarity. If Gyekye is right, the kind of constitutional loyalty that he attempts to promote at this level is as far as one might push events on a continent still steeped in loyalties to ethnocultural groups. It is instructive to note that Gyekye's distinction between first- and second-tier solidarity corresponds to Van der Merwe's (1999:316) distinction between thin and thick multicultural societies.

With thin multiculturalism is meant societies in which the cultural differences which are claimed as rights are embedded in a greater (political) culture, a liberal democratic culture or a culture of universal human rights in which a consensus exists about the right to differences as, for example, has been the case in Belgium until recently. Thick multicultural societies refers to societies, like Israel, wherein certain of the cultural differences which are claimed as rights, undermine a general acknowledgment of the right to difference, for example, when what is demanded is the right to a non-democratic political system, or the prohibition of religious freedom, freedom of speech and so forth.

First-tier solidarity is of the "thick" kind; second-tier solidarity is of the "thin" kind.

\section{- The use of state-backed social and economic rights}

My second point concerns the use of state-backed social and economic rights as backup rights for effective use of political rights. Gyekye accepts the view that money does not lose its class specificity, i.e. it sustains a "self-reproducing class system" (Ryan, 1989:29). Ultimately the problem is due to the fact that the doctrine of rights in the West is welded to an individualist model of the social good in which the right to personhood grew up historically in conjunction with the right to property (Ryan, 1989:152). It is not difficult to see what impact the project of modernity in its liberal pluralist form have had in South Africa. Money and its concomitant social power differentiations, translated into political power, had elevated a white intelligentsia to the status of managers of a capitalist economic system which required labour exploitation as a necessary and rational feature of its operations. If Ryan is right, modernity's attempts to address the social problems which have 
Metanotionality, comprehensive democracy and left communitarian rights

developed in the wake of differential patterns of distribution tend to assimilate difference and marginalize historical identities. This is a source of serious social tension. The problem is clearly that the open market favours those who hold the advantages, irrespective of how those advantages have been accumlated.

Like Gyekye, Ryan thinks the self needs to be reconceptualized. In the multicultural society there is no space for a non-relational self, and by implication, no space for non-relational action in civic or civil society. The self, then, must cease to be an owner for whom rights are property. If this be granted, the right to equal treatment becomes inseparable from its institutional context, and the "interrelational character of social wealth" (Ryan, 1989:117) and hence inseparable from material equality. So the doctrine of rights become a doctrine of exercisable rights" (Ryan, 1989:162). Only a state assisted capacity building programme can ensure that this outcome is achieved. And achieving this outcome is essential to the construction of second-tier solidarity.

\section{- The need for equity between regions}

The last point touches on the need for equity between regions. Thornton (1996:154) believes rightly that the metropolitan regions of South Africa are affluent compared to the rural-traditional regions. "South Africa is a country stretched as thin as a sheet over three points of power and wealth." They are Johannesburg, Cape Town and Durban, veritable "citystates, not just cities" (Thornton, 1996:154), "each with its own identity and allegiances" (Thornton, 1996:154). It is only recently, notes Thornton (1996:157), that a universal politics in which "all persons are the primary units" have been established. But in this set-up the inhabitants of the metropolitan regions have all the advantages, economic and political. At least what they lack by way of direct political clout, they make up by way of economic influence disproportionate to their numbers. Social integration around the idea of a shared constitutional dispensation - a constitutional patriotism - which is a feature of Gyekye's second-tier solidarity, will not be achieved if the means to exercising political rights, means beyond the present political poverty line, remains insufficient and beyond reach.

\section{References}

BERLIN, I. 1969. Four essays on liberty. Oxford: Oxford University Press.

BERNSTEIN, R.J. 1991. Incommensurability and otherness revisited. (In Deutsch, E., ed. Culture and modernity: East West philosophical perspectives. Honolulu University of Hawaii Press. p. 85-103.)

BIRD, C. 1999. The myth of liberal individualism. Cambridge : Cambridge University Press. 
BOHMAN, J. 1997. Deliberative democracy and effective social freedom: capabilities, resources, and opportunities. (In Bohman, J., ed. Deliberative democracy. Cambridge : MIT Press p. 19-23.)

DWORKIN, R. 1989. Liberal community. California Law Review, 77:479-504.

DWORKIN, R. 1990. Foundations of liberal equality. (In The Tanner lectures on human values. Salt Lake City : University of Utah Press. XI p. 49-57.)

DWORKIN, R. 1993. Women and pornography. The New York Review of Books 21:41-44, Oct.

EZE, E C. 1997. Democracy or consensus? A response to Wiredu. (In Eze, E C., ed Postcolonial African philosophy: a critical reader. London : Blackwell. p. 313-323.)

FOUCAULT, M. 1982. The subject and power. Critical Inquiry, 8:777-795

GALBRAITH, J.K. 1983. The anatomy of power. Boston : Houghton Mifflin

GYEKYE, K. 1997. Tradition and modernity: philosophical reflections on the African experience. Oxford : Oxford University Press.

KERNOHAN, A. 1998. Liberalism, equality, and cultural oppression. Cambridge Cambridge University Press.

KYMLICKA, W. 1989. Liberalism, community, and culture. Oxford: Clarendon Press.

LOCKE, J. 1991. A letter concerning toleration. (In Horton, J. \& Mendus, S., eds John Locke - A letter concerning toleration in focus. London : Routledge. p. 12 56.)

LOMASKY, L. 1987. Persons, rights, and the moral community. Oxford : Oxford University Press

MEYERSON, D. 1997. Rights limited. Kenwyn : Juta.

MICHELMAN, F. 1988. Law's republic. Yale Law Journal, 97:1493-1518

MILL, J.S. 1991. On liberty. (In Gray, J. \& Smith, G.W., eds. J.S. Mill - On liberty in focus. London : Routledge. p. 23-128.)

NAGEL, T. 1991. Equality and partiality. New York: Oxford University Press.

NOZICK, R. 1972. Coercion. (In Laslett, P. \& Runciman, W.G., eds. Philosophy, politics and society. Oxford: Oxford University Press. p. 101-135.)

RHODA, E.H. 1990. Group versus individual identity in the African debate on human rights. (In An-Na'im, A.A. \& Deng, F., eds. Human rights in Africa: cross-cultural perspectives. Washington: The Brookings Institute. p. 159-183.)

RAZ, J. 1986. The morality of freedom. Oxford: Oxford University Press

RYAN, M. 1989. Politics and culture: working hypotheses for a post-revolutionary society. London: MacMillan.

SANDEL, M.J. 1982. Liberalism and the limits of justice. Cambridge : Cambridge University Press

SEN A. 1988. Property and hunger. Economic Philosophy, 4:57-68.

TAYLOR, C. 1994. The politics of recognition. (In Goldberg, D.T., ed. Multiculturalism. London : Blackwell. p. 75-106.)

THORNTON, R. 1996. The potentials of boundaries in South Africa: steps towards a theory of the social edge. (In Werbner, R. \& Ranger, T., eds. Postcolonial identities in Africa. London : Zed Books. p. 136-162.)

VAN DER MERWE, W.C. 1999. Cultural relativism and the recognition of cultural differences. South African Joumal of Philosophy, 18(3):313-330.

WALDRON, J. 1995. Minority cultures and the cosmopolitan alternative. (In Kymlicka, W., ed. The rights of minority cultures. Oxford: Oxford University Press. p. 93119.)

WIREDU, K. 1996. Cultural universals and particulars: an African perspective Indianopolis : Indiana University Press. 
Metanotionality, comprehensive democracy and left communitarian rights

YOUNG, I.M. 1990. Justice and the politics of difference. Princeton : Princeton University Press.

YOUNG, I.M. 1992. Five faces of oppression. (In Wartenberg, T.E., ed. Rethinking power. Albany : State University of New York Press. p. 174-195.) (Also printed in Philosophical Forum, 1988. 19:270-290.)

YOUNG, I.M. 1995. Together in difference: transforming the logic of group political conflict. (In Kymlicka, W., ed. The rights of minority cultures. Oxford : Oxford University Press. p. 155-176.)

\section{Key concepts:}

African comnunitarianism and liberalism

African democracy

African philosophy

economic justice

individual rights in the context of a politics of the common good

moral equality - person and community

rights and citizenship

\section{Kernbegrippe:}

Afrika-demokrasie

Afrika-filosofie

Afrika-kommunitarisme en liberalisme

ekonomiese geregtigheid

individuele regte binne die konteks van die politiek van algemene welsyn morele gelykheid - persoon en gemeenskap

regte en burgerskap 